\title{
OS ELEMENTOS CONSTITUTIVOS DO ENUNCIADO EM SUAS RELAÇÕES DIALÓGICAS: UM EXEMPLO DE ANÁLISE
}

\author{
Lucas Vinício de Carvalho Maciel \\ Universidade do Estado do Rio Grande do Norte \\ Faculdade de Letras e Artes \\ Departamento de Letras Vernáculas \\ Mossoró, RN, Brasil
}

\begin{abstract}
Resumo: A partir de propostas do Círculo de Bakhtin, discutimos como os elos dialógicos podem se apresentar em um enunciado real. Para este fim, analisamos uma redação narrativa composta durante a realização da primeira fase do Vestibular Unicamp 2000. $O$ texto é um bom exemplo para se investigar os vínculos dialógicos, pois, nesse vestibular, o candidato precisa dialogar com as instruções da prova e com uma coletânea de textos que embasa a proposta de escrita da redação. A análise proposta mostra, assim, como as relações dialógicas constitutivas do gênero discursivo se manifestam no conteúdo temático, na construção composicional e no estilo desse enunciado.
\end{abstract}

Palavras-chave: Relações dialógicas. Narração. Vestibular Unicamp.

1 INTRODUÇÃO

Neste artigo analisamos uma redação composta por um candidato durante a realização da primeira fase do Vestibular Unicamp 2000. A partir de discussões propostas pelos integrantes do Círculo de Bakhtin, procuramos apreciar como os elos dialógicos se apresentam nesse exemplo de enunciado real.

Como, ao longo de nosso texto, referimo-nos a essa redação através das expressões "narração", "redação narrativa" e "gênero discursivo", é pertinente esclarecer a razão do uso dessas denominações. Ao nomeá-la como "narração", estamos nos reportando à proposta da Comissão Permanente do Vestibular Unicamp (Comvest), que empregava os termos "dissertação", "narração" e "carta argumentativa" para se referir às opções dadas ao vestibulando para confeccionar sua redação naquela oportunidade.

Porém, em consonância com estudiosos como Marcuschi (2002), acreditamos que o termo "narração" é mais adequado para designar um "tipo de texto", uma sequência linguística que pode estar presente em vários gêneros discursivos, não sendo específica ou exclusiva de um único gênero, pois o tipo textual "narração" pode estar presente em vários gêneros: em uma carta pessoal, em um relatório, em uma biografia, etc. Alcunhar a redação como "narração" também não seria totalmente apropriado, se considerarmos

\footnotetext{
Professor Adjunto III. Doutor em Linguística Aplicada/ IEL-Unicamp. E-mail: lucasvcmaciel@yahoo.com.br.
} 
que esse texto pode apresentar, além de sequências narrativas, outras sequências, descritivas e expositivas, por exemplo.

De todo modo, seria impróprio ignorar que a Comvest chancela esses textos sob a rubrica de "narração". Até mesmo porque, no momento em que a Comvest concebeu sua proposta própria de vestibular, o mais comum era se falar em "tipos de texto" ou "tipos textuais", tais como "dissertação", "narração"1. No final da década de 1980 e início da década de 1990, os estudos sobre "gêneros discursivos" já se realizavam no Brasil, mas ainda de modo bastante restrito ao âmbito acadêmico. Assim, falar em "tipos textuais" era algo bem mais conveniente, por ser mais facilmente assimilável pelos vestibulandos e pelos professores que preparavam os candidatos ao vestibular.

Faz-se imperativo, contudo, explicitarmos que, quando nos referimos à redação como "narração", estamos entendendo-a enquanto um gênero discursivo e não como um tipo de texto. Conforme observa Corrêa (2010, p. 636, grifo do autor), "só mais recentemente os exames vestibulares têm tido a preocupação em discernir "tipos de texto' de gêneros do discurso", daí a necessidade de justificar a "nomeação de textos produzidos em situação de vestibular como gêneros do discurso". Segundo Corrêa (2010, p. 637), há uma série de particularidades que configuram a redação do/no vestibular $^{2}$ como um gênero do discurso: "a interação social específica (avaliado/avaliador)", "escolhas temáticas filtradas por um interesse educacional", "soluções estilísticas essencialmente ligadas ao diálogo com a instituição avaliadora". Entendemos, assim, que as redações são representantes de um gênero discursivo, pois são enunciados reais, materializados em condições sociais e discursivas definidas. Dessa maneira, a despeito da denominação do texto como "narração", o que poderia dar a entender que se trata de um "tipo textual", assumimos a redação como um gênero discursivo, pois é um enunciado que se define em condições específicas de comunicação.

Além disso, também respeitamos a denominação proposta pela Comvest, pois é habitual se empregar termos mais genéricos como "narração" e "narrativa" para se designar textos com predomínio de sequências narrativas. É ainda nesse sentido de sua sequência textual mais característica que, em certas ocasiões, empregamos a expressão "redação narrativa" para nos referirmos ao texto do vestibulando.

O objetivo de analisar a redação é empregá-la como exemplo para se discutir como os elos dialógicos são relevantes na configuração do enunciado. Para isso, baseamo-nos em propostas de integrantes do Círculo de Bakhtin ${ }^{3}$ (BAKHTIN, 2003

\footnotetext{
1 A partir de 1987, através da recém-criada Comissão Permanente para os Vestibulares Unicamp (Comvest), a Unicamp passa a ter vestibular próprio, deixando o certame de ser realizado pela Fundação Universitária para o Vestibular (Fuvest), conforme vinha ocorrendo desde 1977.

2 Corrêa fala em "gênero redação de vestibular", Brito (2011) em "gênero redação de vestibular" ou "gênero redação no vestibular".

3 Empregamos a expressão "Círculo de Bakhtin" por ainda ser a mais corrente no contexto brasileiro, embora mais recentemente venha ganhando difusão a partir das pesquisas conduzidas ou influenciadas por Beth Brait o sintagma "Bakhtin e o Círculo". Advertimos, porém, que certos pesquisadores propõem outras denominações com menor destaque à figura de Bakhtin. Vauthier (2007), por exemplo, prefere a denominação "Cercle Bakhtine, Medvedev, Volochinov", abreviada como "Cercle B.M.V.", ao entender que, assim, outros membros do grupo são também contemplados.
} 
[1952-1953]; MEDVEDEV/BAKHTIN, 1994 [1928]; VOLOŠINOV, 1986 [1929]), assumindo que todo enunciado, qualquer texto oral ou escrito, estabelece vínculos com textos antecedentes e suscita respostas futuras, a serem materializadas em enunciados vindouros. Da perspectiva bakhtiniana, portanto, a linguagem se constitui como uma espécie de diálogo na medida em que todo enunciado retoma vozes anteriores e pode, igualmente, ser empregado em discursos futuros.

Consideramos ainda que todo enunciado é composto por três elementos constitutivos - o conteúdo temático, a construção composicional e o estilo - e que qualquer enunciação se realiza de acordo com características típicas de um determinado gênero do discurso (cf. BAKHTIN, 2003 [1952-1953]). Investigar como as relações dialógicas, que perpassam os elementos constitutivos do enunciado, são importantes para sua configuração é o que pretendemos ao apreciar a redação, um enunciado real, representante do gênero discursivo que estamos nomeando como "narração".

É possível imaginar que não se avança qualquer novidade ao se apreciar um enunciado a fim de mostrar sua constituição dialógica, haja vista que entender os enunciados como dialogicamente constituídos é algo bastante consensual nos estudos linguísticos, chegando o dialogismo a figurar, nas reflexões sobre a linguagem, como uma premissa repetida ad nauseum. Entretanto, vários pesquisadores têm alertado acerca de certo imediatismo com o qual diversas das complexas discussões bakhtinianas vêm sendo assimiladas e, posteriormente, difundidas. Já há algum tempo, por exemplo, Gomes-Santos (1999, p. 177-178) apontava para "um reducionismo que se tem tornado frequente quando da referência ao conceito de gênero em Bakhtin". Colocações como essa ainda persistem, como observamos em trabalhos mais atuais em que se pontua, por exemplo, ser "oportuno lembrar que a complexidade do conceito de gênero discursivo pode ser mais bem captada ao expandirmos nossas leituras [para além do texto "Os gêneros do discurso"] e percorrermos outros textos que tratam da questão" (MACIEL, 2011, p. 27). Brait e Pistori (2012, p. 372) são ainda mais assertivas, ao afirmarem que o ensaio "Os gêneros do discurso" é "citado e tomado como único", o que reduz certas postulações bakhtinianas.

Para evitar esses reducionismos, pretendemos discutir neste trabalho que as relações dialógicas não são relações abstratas e genéricas, que se resumiriam a certas referências de um texto ao outro. Concepção essa talvez influenciada pela noção de intertextualidade, com a qual Kristeva (2012 [1967]) entende - e reduz ${ }^{4}$ - a ideia de dialogismo. Nossa proposta é explicitar que as relações dialógicas são concretas e podem ser vislumbradas em todos os elementos constitutivos do enunciado, indo além do entendimento de que as relações dialógicas seriam apenas referências entre textos, que se aproximariam apenas por abordar assuntos, temas ou ideias próximos.

\section{A REDAÇÃO NO CONTEXTO DO VESTIBULAR UNICAMP}

Na primeira fase do Vestibular Unicamp 2000, contexto no qual a redação que analisaremos foi redigida, o candidato poderia escolher entre propostas: dissertação,

\footnotetext{
${ }^{4}$ A respeito ver Bezerra (2010).
} 
narração e carta argumentativa ${ }^{5}$. Para cada um desses gêneros, propunha-se certo tratamento do tema da prova. Desse modo, o vestibulando poderia escolher o gênero, mas em função de sua opção, deveria abordar o tema necessariamente de determinado modo. Relação diversa se coloca em uma situação comum de comunicação, segundo Bakhtin (2003 [1952-1953], p. 282, grifo do autor):

\begin{abstract}
A vontade discursiva do falante se realiza antes de tudo na escolha de um certo gênero de discurso. Essa escolha é determinada pela especificidade de um dado campo da comunicação discursiva, por considerações semântico-objetais (temáticas), pela situação concreta da comunicação discursiva, pela composição pessoal dos seus participantes, etc. A intenção discursiva do falante, com toda a sua individualidade e subjetividade, é em seguida aplicada e adaptada ao gênero escolhido, constitui-se e desenvolve-se em uma determinada forma de gênero.
\end{abstract}

Ou seja, de acordo com Bakhtin, o sujeito elege um gênero, confiando ser este o mais adequado para expressar seu projeto discursivo. Isto é, o falante ou escrevente adapta sua "vontade discursiva" a um gênero, levando em consideração o quanto este gênero é apropriado para versar sobre o tema que pretende discorrer e avaliando também as características do "campo da comunicação discursiva" em que concretizará seu enunciado.

Desse modo, se comumente, em um evento de comunicação, o sujeito seleciona o gênero a partir do tema que quer tratar, no contexto desse vestibular essa relação é um pouco distinta. Realizando sua prova, o vestibulando não elegerá livremente o gênero a partir do tema, pois há uma ligação entre gênero e tema: a escolha de um tema implica tratá-lo em um gênero específico.

No vestibular de 2000, por exemplo, o candidato que preferisse a dissertação deveria ponderar sobre a relação entre a água, a cultura e o desenvolvimento das civilizações; o vestibulando que selecionasse como gênero a narração deveria desenvolver uma história em que um personagem buscasse esclarecer um suposto crime ambiental - o aparecimento de uma mancha de óleo no Rio Atibaia -, o que comprometera o abastecimento de água de várias pessoas; por fim, os que preferiram a carta argumentativa precisavam defender a criação da Agência Nacional da Água (ANA), dirigindo-se a um deputado ou senador contrário ao estabelecimento desse órgão.

Se, por um lado, o vínculo entre tema e gênero já está colocado pelo vestibular, de modo que os candidatos não selecionam livremente o gênero em razão do tema, o que diferencia essa conjuntura daquilo que é mais comum em outras situações de comunicação, por outro, a necessidade de "responder" (em sentido amplo) às instruções da prova torna essas redações interessante material para a investigação das relações dialógicas. No caso das indicações para a escrita da narração, por exemplo, havia uma reportagem que subsidiava a proposta e esse texto deveria ser necessariamente empregado pelo vestibulando na confecção de sua redação. Nesse contexto enunciativo, portanto, é provável que os textos dos candidatos exibam, de modo razoavelmente explícito, os elos dialógicos que unem sua voz às palavras alheias retomadas.

\footnotetext{
5 Discutimos mais detalhadamente as propostas da dissertação e da carta argumentativa em nossa dissertação de mestrado, Gênero e estilo nas melhores redações do vestibular Unicamp (MACIEL, 2008).
} 
Isso não significa, porém, que somente nas redações, à diferença de outros enunciados, seja possível observar relações dialógicas. Destacamos apenas que, nessa conjuntura do vestibular Unicamp, o candidato deveria dialogar explicitamente com a coletânea e com a proposta que o subsidiavam e orientavam para a confecção de seu texto. Assim, seria de se esperar que as redações escritas nessa situação enunciativa exibissem mais claramente vínculos dialógicos, que talvez em outros enunciados se apresentassem de modo menos evidente.

Foi ainda levando em consideração a questão da presença manifesta de vínculos dialógicos que escolhemos uma redação, que, julgamos, apresenta de modo bastante claro elos com outras vozes. A redação escolhida faz parte de um corpus $^{6}$ constituído por 111 textos eleitos pela Comvest como os melhores representantes da proposta de escrita da narração dos vestibulares Unicamp de 2000 a $2010^{7}$. Essas redações foram publicadas, com apoio da Comvest, em coletâneas compostas também por redações que atenderam às propostas da dissertação e da carta argumentativa. $\mathrm{O}$ objetivo dessas publicações é valorizar o empenho dos estudantes, cujos textos são reconhecidos pela instituição como exemplares.

Dentro desse corpus, nossa escolha se deu através da leitura das redações e comparação entre elas, para que selecionássemos uma que cremos ser bastante representativa dos elos dialógicos que pretendemos apreciar neste artigo. Podemos dizer que optamos por essa redação porque esse texto se "destacou" a nossos olhos, baseando-nos, de algum modo, em "elementos imponderáveis: faro, golpe de vista, intuição", ou seja, em "formas de saber tendencialmente mudas - no sentido de que [...] suas regras não se prestam a ser formalizadas nem ditas" (GINZBURG, 1986, p. 179, grifo do autor). Por isso, admitimos nos ser bastante difícil (se possível) explicitar todos os princípios dessa nossa escolha, que, além da comparação, funda-se também em "faro", "golpe de vista" ou "intuição".

\section{FUNDAMENTAÇÃO TEÓRICA: AS RELAÇÕES DIALÓGICAS NA CONSTITUIÇÃO DO ENUNCIADO}

No âmbito do Círculo de Bakhtin, entende-se que toda "palavra é uma ponte lançada entre mim e o outro"8 (VOLOŠINOV, 1986 [1929], p. 86, tradução nossa). Assim, para o "estudo da natureza do enunciado" (BAKHTIN, 2003 [1952-1953], p. 264), é imprescindível considerar as relações dialógicas. Daí nosso interesse em investigar como os elos dialógicos podem se manifestar nos três elementos constitutivos do enunciado: "o conteúdo temático, o estilo, a construção composicional" (BAKHTIN, 2003 [1952-1953], p. 261-262).

\footnotetext{
6 Esse corpus foi analisado em nossa pesquisa de doutorado (MACIEL, 2014, Processo CNPq 141428/2011-12).

${ }^{7}$ A partir do Vestibular Unicamp 2011, as propostas para escrita da redação têm trazido gêneros diversos a cada ano. Em 2011, por exemplo, solicitou-se a escrita dos gêneros comentário, discurso de apresentação de evento e artigo jornalístico opinativo, enquanto, em 2012, propôs-se que o vestibulando escrevesse um comentário, um manifesto e um verbete. As propostas completas podem ser consultadas em www.comvest.unicamp.br.

${ }^{8}$ The word is bridge throw between myself and another.
} 
Diante desse objetivo, parece-nos válido comentar algumas das particularidades de cada um desses elementos. Iniciemos pela questão da construção composicional.

A discussão sobre a forma ou estrutura composicional dos enunciados está exposta em vários trabalhos do Círculo de Bakhtin sob nuanças diversas, ainda que, em geral, próximas. Em O problema do conteúdo, do material e da forma na criação literária (BAKHTIN, 1993 [1924]), escrito em 1924 e publicado na coletânea de textos Questões de literatura e de estética: a teoria do romance, Bakhtin estabelece uma comparação entre forma arquitetônica e forma composicional. Aquela seria o projeto de dizer do autor e esta a textualização desse projeto. A forma composicional seria, em certo sentido, o acabamento geral de um texto e se configuraria, inclusive, como algo próximo ao que se denomina gênero discursivo. Segundo Grillo (2007, p. 30, tradução nossa): "É de se notar que, nesse texto [O problema do conteúdo, do material e da forma na criação literária], o gênero equivale aproximadamente à forma composicional" ${ }^{\prime \prime}$. A autora comenta ainda que nesse ensaio a forma composicional seria a "organização [que] se passa ao nível da totalidade e da articulação das partes, dirigidas para um fim"10, pontuando também que em termos "da articulação das partes, ele [Bakhtin] menciona o capítulo, a estrofe, o verso, o parágrafo, as linhas, as palavras"11 (2007, p. 30, tradução nossa). De certo modo, portanto, a forma composicional seria o esquema geral do texto, assim como sua estruturação textual em partes.

No limite até se poderia imaginar que a construção ou forma composicional seria uma espécie de "fôrma", um esquema espacial para a composição do enunciado, que preveria certa extensão do texto e certa disposição dos parágrafos.

Entretanto, ainda que se admitisse esse conceito de forma composicional como algo próximo a uma "fôrma", seria necessário lembrar que essa "fôrma" é, antes de tudo, flexível. Isso porque são variáveis tanto a extensão de um texto (falado ou escrito) quanto sua organização em parágrafos (no caso do texto escrito). A forma composicional não existe como uma "fôrma" vazia, mas como enunciado real e único, com sua extensão e disposição gráfica própria. É ao ganhar conteúdo que a forma ganha definição. Isso vai ao encontro da indissociabilidade entre forma e conteúdo postulada por Medvedev/Bakhtin (1994 [1928], p. 222, tradução nossa): "Não há conteúdo sem forma, como não há forma sem conteúdo" $"$.

Ao escrever, o enunciador desenvolve o conteúdo temático, cuja forma se configura durante a escrita. Quando chega ao final de seu texto, o escrevente cunhou o que pretendia dizer por meio de certo número de parágrafos, cada um com sua extensão. O conjunto desses parágrafos conferiu, por sua vez, o aspecto composicional final. Assim, a forma composicional do texto só é conhecida após o sujeito encerrar seu ato de dizer, após concluir o que desejava dizer. O tema careceu de uma forma para ser expresso e, conforme foi sendo veiculado, conferiu um caráter único à forma. É a forma

\footnotetext{
${ }^{9} \mathrm{Il}$ faut remarquer que, dans ce texte, le genre équivaut à peu près à la forme compositionnelle.

${ }^{10}[\ldots]$ organisation [qui] se passe au niveau de la totalité et de l'articulation des parties, dirigée vers un but.

${ }^{11}$ [...] d'articulation des parties, il [Bakhtin] mentionne le chapitre, la strophe, le paragraphe, les lignes, les mots.

${ }^{12}$ No hay contenido sin forma, como no hay forma sin contenido.
} 
daquele texto, não de outro. É à medida que o conteúdo vai sendo expresso que a "fôrma" ganha forma (e sentido). Há, portanto, uma relação de dependência entre forma e conteúdo temático, pois todo projeto discursivo sempre requisitará uma forma composicional, característica de um gênero específico.

Mas se forma e conteúdo são interdependentes, cada um desses elementos ainda mantém predicados próprios. Por isso é que focalizaremos a partir de agora, em nossa exposição, propriedades mais específicas do conteúdo temático.

Segundo a concepção bakhtiniana, o conteúdo temático está fundamentado em vínculos dialógicos que o enunciado estabelece com outros textos, uma vez que os "enunciados não são indiferentes entre si nem se bastam cada um a si mesmos; uns conhecem os outros e se refletem mutuamente uns nos outros." (BAKHTIN, 2003 [1952-1953], p. 297).

Ao lançar sua voz, o falante ou escrevente sempre considera, em certa medida, vozes outras que estão relacionadas com seu texto. Isso porque qualquer enunciado "por mais concentrado que esteja no seu objeto, não pode deixar de ser em certa medida também uma resposta àquilo que já foi dito sobre dado objeto, sobre dada questão [...]" (BAKHTIN, 2003 [1952-1953], p. 298). Ao compor seu enunciado, o sujeito não tem como foco apenas o tema ou assunto - o "objeto" na expressão de Bakhtin - que aborda. O enunciador leva em conta também outras enunciações, que estão correlacionadas ao tema ou assunto de que trata seu texto.

Como nota Bakhtin (2003 [1952-1953], p. 299-300):

\begin{abstract}
O objeto de discurso do falante, seja esse objeto qual for, não se torna pela primeira vez objeto do discurso em um dado enunciado, e um dado falante não é o primeiro a falar sobre ele. O objeto, por assim dizer, já está ressalvado, contestado, elucidado e avaliado de diferentes modos; nele se cruzam, convergem e divergem diferentes pontos de vista, visões de mundo, correntes.
\end{abstract}

Ou seja, o conteúdo temático do enunciado é palco dos elos dialógicos que ligam o objeto de discurso do enunciado a outras vozes, que já versaram acerca daquele mesmo "objeto". Entendemos, assim, que estudar o tema da enunciação, sob uma perspectiva bakhtiniana, é mais do que descrever o "tema" ou "assunto" de uma fala ou texto. É necessário vislumbrar as relações dialógicas através das quais o conteúdo temático se constitui.

É ainda observando a relevância das relações dialógicas na configuração da enunciação, que passamos a discorrer sobre o estilo, outro elemento constitutivo do enunciado (cf. BAKHTIN, 2003 [1952-1953]).

Segundo Bakhtin (2003 [1952-1953], p. 265): “Todo enunciado [...] é individual e por isso pode refletir a individualidade do falante (ou de quem escreve), isto é, pode ter estilo individual". A manifestação do estilo, assim, seria possível em qualquer texto, pois todo enunciado poderia acolher marcas idiossincráticas do falante ou escrevente. Aliás, Bakhtin (2003 [1952-1953], p. 268) pontua que "a própria escolha de uma determinada forma gramatical pelo falante é um ato estilístico". Isto é, até mesmo as eleições gramaticais que qualquer falante realiza ao compor um enunciado indicariam algum estilo do autor. 
Contudo, se, por um lado, Bakhtin reconhece ser possível o exercício das escolhas estilísticas em quaisquer enunciados, por outro, não deixa de observar que há gêneros mais propícios à manifestação do estilo, assinalando que "nem todos os gêneros são igualmente propícios a tal reflexo da individualidade do falante na linguagem do enunciado, ou seja, ao estilo individual. Os gêneros mais favoráveis [são os] da literatura de ficção [...]”. (BAKHTIN, 2003 [1952-1953], p. 265).

Bakhtin reconhece, desse modo, ser possível a emergência do estilo em qualquer enunciado, mas nota que os gêneros discursivos têm importante papel na execução das opções do autor. Reconhecendo que o "estilo está indissoluvelmente ligado ao enunciado e às formas típicas de enunciados, ou seja, aos gêneros do discurso" (BAKHTIN, 2003 [1952-1953], p. 265), a concepção bakhtiniana se desloca da ideia de estilo como fenômeno exclusivamente individual, pois vincula as eleições estilísticas ao gênero discursivo em que se materializa o enunciado.

Além disso, Bakhtin (2003 [1952-1953], p. 306, grifo do autor) acredita que a "análise estilística, que abrange todos os aspectos do estilo, só é possível como análise de um enunciado pleno e só naquela cadeia da comunicação discursiva da qual esse enunciado é um elo inseparável”.

Assim, a exemplo do conteúdo temático e da construção composicional, o autor adverte que para apreciar o estilo é preciso interpretá-lo no interior das relações dialógicas que ligam o enunciado a outras vozes da cadeia discursiva.

A partir dessas colocações de Bakhtin, julgamos que o estilo pode comportar opções individuais do autor, mas consideramos que as escolhas estilísticas estão também sob o crivo do gênero discurso e são perpassadas por elos dialógicos.

Será com base nessas reflexões que passamos, a seguir, à análise da redação, especialmente interessados em observar como os vínculos dialógicos atuam na composição, no conteúdo temático e no estilo do enunciado.

\section{ANÁLISE DA REDAÇÃO}

A redação, que tomamos como objeto de exame, foi redigida durante a realização da primeira fase do Vestibular Unicamp 2000 por Christianne Basílio e Silva ${ }^{13}$, então candidata ao curso de Engenharia Elétrica. A vestibulanda optou pelo Tema B (narração), reproduzido a seguir:

\section{TEMA B}

No dia 5 de outubro de 1999, terça-feira, o jornal Correio Popular, de Campinas, SP, publicou a seguinte manchete de primeira página, acompanhada de breve texto:

\footnotetext{
${ }^{13}$ Não omitimos o nome da candidata, pois é pública a autoria das redações que compõem as coletâneas organizadas pela Comvest. Além disso, consideramos meritória a referência a candidatos cujos textos se destacam no conjunto dos milhares que a cada ano são avaliados pela Comvest.
} 


\title{
100 mil ficam sem água em Sumaré
}

Um crime ambiental provocou a suspensão do abastecimento de água de cerca de $100 \mathrm{mil}$ moradores de Sumaré. A medida foi tomada na sexta-feira, quando uma mancha de óleo de aproximadamente 3 quilômetros de extensão surgiu nas águas do rio Atibaia. Anteontem, uma nova mancha apareceu nas proximidades da Estação de Tratamento de Água I, na divisa entre o bairro Nova Veneza e o município de Paulínia. A situação somente será normalizada na quinta-feira. A Cetesb investiga o caso e os técnicos acreditam que o produto (óleo diesel ou gasolina) foi despejado em esgoto doméstico em Paulínia.

Leve em conta essa notícia e privilegie a hipótese dos técnicos, apresentada no final do texto. A partir desses elementos, escreva uma narração em terceira pessoa, caracterizando adequadamente personagens e ambiente. Crie um detetive ou um repórter investigativo que, quando tenta resolver o "crime ambiental", descobre que o ocorrido é parte de uma conspiração maior.

A partir dessa instrução, a candidata elabora a seguinte redação (COMVEST, 2000, p. 122-126):

\section{Conspiração}

\author{
“... e, na brancura asséptica de nossos \\ banheiros, fingimos esquecer das imensas, \\ verdadeiras Venezas de merda (sic) que \\ correm debaixo de nossas casas, de nossas \\ ruas e de nossos parlamentos." \\ Milan Kundera, in A insustentável leveza do ser
}

\begin{abstract}
"Que irônico!", pensou Policarpo, que não fazia senão ler jornais e revistas desde que se aposentara, poucos meses antes; "logo hoje, aniversário de nossa Constituição regente, será que ninguém reconhece?". Do alto de seu arraigado e ingênuo patriotismo, indignava-se com o fato de que só uns poucos arquivistas e historiadores, além dele, teriam feito a mesma observação ao ler a notícia veiculada no Correio Popular daquela manhã, segundo a qual cem mil pessoas da região ficariam sem água por três dias, por conta de um derramamento proposital de combustível na rede de esgotos que deriva do rio Atibaia, um verdadeiro crime ambiental. Mas, se refletisse melhor, retirando os óculos auriverdes, veria que semelhantes atentados à pátria mãe gentil ocorrem todos os santos dias, e a única coisa nisso tudo que tinha data específica para acontecer era a promulgação da nossa Constituição, portanto a única culpada pela coincidência infame de datas, ora essa! De qualquer forma, não pensou nisso: seu cérebro, excitado com a proximidade - Policarpo morava em Campinas, a minutos de Paulínia pela General Tavares - e as proporções do crime, vagueava por entre os enredos fantásticos dos muitos livros policiais e de mistério que lera, de Raymond Chandler a Dorothy Parker, de Aghata Christie a Conan Doyle, de Edgar Wallace a Allan Poe, e começava a maquinar se bancar o detetive não seria a solução ideal para espantar de vez o marasmo em que sua vida submergira desde sua recente aposentadoria.
\end{abstract}

Ao cabo de alguns minutos, decidiu-se; ato contínuo, levantou-se da poltrona e, pegando as chaves do carro, tomou dali o rumo da rua.

O local a que se dirigiu foi o próprio escritório da CETESB, onde trabalhava um antigo conhecido seu, que, achando até um pouco de graça no pedido, prontamente o conduziu ao lugar onde trabalhavam os técnicos empenhados em apurar a origem do óleo poluente. Conversando com eles, pôde ver que, usando critérios e métodos de deteç̧ão avançados, eles já haviam descoberto que o material viera de um conjunto habitacional em Paulínia próximo à REPLAN. No entanto, seria necessária uma investigação policial para identificar 
de que casa específica ele teria partido; os contatos já haviam sido feitos com a polícia municipal de Paulínia e a estadual, mas cada qual alegou estar o caso fora de sua alçada, atribuindo-o à outra, e era nesse pé que a investigação se encontrava, naquele momento.

Finda a explanação, um súbito palpite perpassou a mente de Policarpo, fazendo-o estremecer. E esse palpite segredou-lhe ao ouvido que não seriam necessárias senão simples entrevistas, que ele estaria apto a realizar. Cismado, pediu aos técnicos o endereço do conjunto, que eles lhe deram sem nada esperar. Com ele nas mãos, despediu-se de todos, e para lá rumou.

Muitas foram as prosas e muitos cafezinhos gentilmente oferecidos que Policarpo em vão ouviu e tomou, durante toda a tarde, até que, já caindo a noite, chegou a uma casa cuja dona, quando indagada a respeito, em poucas palavras confirmou seu funesto palpite: "O senhor está falando daquela 'lataiada' velha que meu pai guardava no galpão? Aquilo não prestava não... Meu velho era meio doido, trabalhava na refinaria e cada semana trazia uma porcaria daquelas p'ra cá. Meu irmão disse que aquilo era como um tal de paiol pronto p'ra explodir, que eu tinha que me livrar daquilo. Então, como eu sei que faz fogo, joguei tudo fora, um por um, na "privada'!"

Policarpo permaneceu silencioso. O que ele pensara ser um crime ambiental era na verdade parte de uma conspiração muito maior, gigante pela própria natureza, com a qual não estava preparado para lutar; um plano verdadeiramente diabólico tramado para subjugar todo um povo, delatado pela extrema ignorância da mulher à sua frente, dos milhões como ela que por aí grassam. O patriotismo que por meio século conservara começou a fenecer em sua alma. Suspirou. Amava o Grande Irmão.

Em nosso exame da redação, observaremos separadamente o conteúdo temático, a construção composicional e o estilo, a fim de alcançarmos uma apreciação mais pontual de cada elemento, não deixando, porém, de relacioná-los, quando julgarmos necessário, até mesmo porque reconhecemos estarem esses elementos "indissoluvelmente ligados no todo do enunciado" (BAKHTIN, 2003 [1952-1953], p. 262).

\subsection{CONSTRUÇÃO COMPOSICIONAL}

Por forma ou construção composicional, entendemos a configuração geral do texto, sua disposição e organização em partes. No caso da redação, o arranjo composicional se dá através de seis parágrafos, de extensão bem diversa, por meio dos quais o tema é desenvolvido.

Além desses seis parágrafos, destaca-se o fato de que a candidata anteponha à narrativa uma citação, uma espécie de epígrafe, que cria um espaço composicional específico em seu texto. Isso é bastante particular a essa redação e, cremos, pode ser considerado como algo do estilo individual da vestibulanda ${ }^{14}$. Afirmamos com isso que as escolhas estilísticas do autor têm também implicações composicionais. O que torna ainda mais singular essa epígrafe é o fato de que o fragmento citado (trecho de "A insustentável leveza do ser" de Milan Kundera) não estava presente na prova, sendo trazido "de memória" pela candidata.

A nosso ver, mesmo esse fato singular pode indicar que a estrutura composicional da redação se funda em elos dialógicos, pois acreditamos que, ao compor sua narrativa, a estudante recorreu a alguns modelos, entre os quais pôde observar o uso de epígrafes.

\footnotetext{
${ }^{14}$ Essa ocorrência é única entre as 111 redações que compõem o corpus de nossa pesquisa.
} 
Mais do que isso, supomos que toda a estrutura composicional do texto esteja embasada por modelos que a candidata provavelmente trouxe de seu conhecimento prévio, pois como observa Bakhtin (2003 [1952-1953], p. 283), se "os gêneros do discurso não existissem e se nós não os dominássemos, se tivéssemos de criá-los pela primeira vez no processo do discurso, de construir livremente e pela primeira vez cada enunciado, a comunicação discursiva seria quase impossível."

Assim, o enunciador não cria o gênero, mas se volta ao passado em busca de alicerces para arquitetar seu enunciado. Resta, contudo, saber quais seriam as bases dessa sua enunciação. Nossa crença é que a vestibulanda tenha tido contato com textos narrativos na escola e é de se imaginar que nessa instância passou por algum ensino formal sobre narrativas. Além disso, a candidata pôde ter acesso a materiais da Comvest em que a instituição traz indicações a respeito do que espera em uma narração e expõe também exemplos de narrativas redigidas em vestibulares anteriores.

Imaginando, então, que um participante do Vestibular Unicamp 2000 tenha lido o Manual do Candidato publicado pela Comvest comentando o Vestibular 1999, vejamos a que espécie de informação ele teria acesso quanto à composição de uma narrativa. A Comvest adverte que se o candidato "escolher um tema narrativo, deverá ser capaz de elaborar enredo, personagens, espaço e tempo, demonstrando conhecimento da estrutura de uma narrativa" (COMVEST, 1999, p. 33, grifo nosso).

Além disso, a Comvest (1999, p. 33) recomenda que:

Para a produção de um texto narrativo, você [o candidato] deve estar atento às informações que acompanham o tema proposto, mostrando saber reconhecer nelas elementos de enredo, personagens, cenário, tempo e foco narrativo, que deverão ser utilizados por você na construção da sua narrativa, segundo instruções fornecidas pela banca.

A partir desses comentários, vemos que os apontamentos da Comvest quanto à narração se dão em termos de: enredo, personagens, cenário, tempo, foco narrativo. Porém a menção a esses elementos da "estrutura de uma narrativa" parece insuficiente para orientar o vestibulando na confecção de seu texto. Desse modo, é difícil saber se e como as indicações da Comvest podem atingir os candidatos. Ainda assim, arriscamonos a dizer que a forma composicional deve ter uma origem dialógica, mesmo que seja complexo recuperar essa ascendência. Nossa hipótese é a de que os fundamentos da estrutura composicional do texto da vestibulanda derivem de enunciados narrativos com os quais ela teve contato em sua vida pregressa e que talvez sua redação possa também estar influenciada por algumas das pontuações da Comvest.

\subsection{CONTEÚDO TEMÁTICO}

O conteúdo temático é aquilo que o enunciador pretende dizer. Projeto de dizer que, alicerçado pela forma composicional característica de um gênero discursivo, estabelece vínculos dialógicos com outros textos. São justamente esses elos que pretendemos focalizar ao observar como a candidata faz uso da coletânea e de outras vozes alheias no desenvolvimento de sua redação. 
$\mathrm{Na}$ redação em análise, o delineamento do conteúdo temático se inicia já pelo título "Conspiração". Ocupando um espaço composicional específico, destacado do restante do texto, o título expõe desde o início o caráter dialógico da redação ao atender à exigência de que se "Crie um detetive ou um repórter investigativo que, quando tenta resolver o 'crime ambiental', descobre que o ocorrido é parte de uma conspiração maior” (COMVEST, 2000, p. 114, grifo nosso). Além disso, o título focaliza a resolução do conflito narrativo, quando se chega à descoberta da "conspiração", momento em que o personagem principal desvenda, nas palavras da vestibulanda, "uma conspiração muito maior, gigante pela própria natureza".

Após o título, a candidata cita - em peculiar espaço composicional - trecho da obra "A insustentável leveza do ser" de Milan Kundera. Esse excerto, empregado como epígrafe, evoca uma reflexão sobre as "imensas, verdadeiras Venezas de merda que correm debaixo de nossas casas, de nossas ruas e de nossos parlamentos". O texto metafórico alude às injustiças que subjazem à aparente ordem social. Uma ordem criticada no texto da vestibulanda em que se denuncia "um plano verdadeiramente diabólico tramado para subjugar todo um povo".

Após título e epígrafe, abre-se a narração propriamente dita. O protagonista da ação, Policarpo, é, então, apresentado. O nome pouco usual remete imediatamente o leitor brasileiro ao personagem homônimo do romance Triste fim de Policarpo Quaresma de Lima Barreto. Aliás, não será apenas o nome que os personagens apresentarão em comum, mas o traço mais marcante de ambos: um "arraigado e ingênuo patriotismo". Ao atender à exigência da prova e conceber "um detetive ou um repórter investigativo", a candidata buscou - dialogicamente, diríamos - uma referência na literatura nacional, valendo-se não apenas do nome, mas de conhecidas características do famoso personagem barretiano.

Policarpo está em sua casa, quando lê "a notícia veiculada no Correio Popular daquela manhã, segundo a qual cem mil pessoas da região ficariam sem água por três dias, por conta de um derramamento proposital de combustível na rede de esgotos que deriva do rio Atibaia, um verdadeiro crime ambiental". Falar sobre essa notícia, claro, é dialogar com a reportagem "100 mil ficam sem água em Sumaré", que serve de coletânea à proposta da redação.

O patriótico Policarpo atenta-se para um "fato [...] que só uns poucos arquivistas e historiadores, além dele" teriam notado. Trata-se da coincidência de datas entre a publicação da reportagem, veiculada em 5 de outubro de 1999, mesmo dia e mês da promulgação da Constituição da República Federativa do Brasil, episódio ocorrido em 5 de outubro de 1988. Essa é apenas uma das inúmeras referências dialógicas que a autora cultivará ao cunhar seu personagem nacionalista.

A notícia também enseja o desenrolar narrativo, pois é a partir da leitura da reportagem que o recém-aposentado Policarpo decide buscar por conta própria os responsáveis pelo que julga ser um crime ambiental. Seu ímpeto se deve a dois fatores: à proximidade de sua cidade, Campinas, ao munícipio de Paulínia, provável local de origem das manchas de óleo e - talvez razão principal - à influência das leituras de literatura detetivesca, entre as quais o narrador cita Raymond Chandler, Dorothy Parker, Aghata Christie, Conan Doyle, Edgar Wallace e Allan Poe. A alusão a esses autores 
manifesta o diálogo da redação com outras narrações, um diálogo estabelecido entre o narrador e vozes exteriores a seu texto ${ }^{15}$.

Determinado a ir a Paulínia, Policarpo se dirige ao "próprio escritório da CETESB, onde trabalhava um antigo conhecido seu". Esse conhecido o conduz aos técnicos que investigam o caso, tendo esses profissionais já "descoberto que o material viera de um conjunto habitacional em Paulínia próximo à REPLAN". Diante disso, Policarpo resolve ir pessoalmente ao conjunto habitacional e realizar a investigação, que se encontrava paralisada em razão do conflito entre a polícia do munícipio de Paulínia e a polícia estadual de São Paulo, uma vez que "cada qual alegou estar o caso fora de sua alçada, atribuindo-o à outra". Essa circunstância serve de estopim a ações do protagonista, resolvido a fazer "simples entrevistas, que ele estaria apto a realizar". Ao abordar essa situação, o texto dialoga com tantos episódios reais - comuns no Brasil em que a querela entre as diferentes instâncias governamentais quanto à responsabilidade perante uma situação acaba por dificultar qualquer solução.

Em seu inquérito, Policarpo visita inúmeros domićlios, até que, “já caindo a noite", encontra nas palavras de uma mulher a resposta para o caso. Ela jogara o óleo na privada de sua casa, sem desconfiar que pudesse comprometer todo um rio e prejudicar o abastecimento de água de várias pessoas.

Se, por um lado, esse é o desfecho da ação narrativa, por outro, o texto avança, pois diante da inocência - ou ignorância, na voz do narrador - da mulher, Policarpo verá abalado o nacionalismo que cultivou por toda a vida. Perceberá como seu patriotismo é infundado, ao compreender algo ignorado por ele até então: certos artifícios dirigidos no sentido de "subjugar todo um povo". Ardis contra as quais ele "não estava preparado para lutar". Policarpo divisa, enfim, o que seu ingênuo patriotismo ocultara: diferentemente dele, alguns representantes de seu país, por vezes, não almejavam o desenvolvimento da nação. Frente a tamanha decepção, o personagem declara amor à vigilância estatal imposta pelo vulto do "Grande Irmão", em mais um elo dialógico que o enunciado estabelece com vozes alheias.

Além de sublinhar a importância dos elos dialógicos no desenvolvimento temático dessa redação, julgamos importante também lembrar que o conteúdo temático desse enunciado se efetiva de um modo e não de outro por ser esse um texto narrativo. Segundo Medvedev/Bakhtin (1994 [1928], p. 210, tradução nossa), cada gênero imprime modos próprios de expressão: "Cada gênero é capaz de abarcar tão somente determinados aspectos da realidade. Cada gênero possui determinados princípios de seleção, determinadas formas de visão e de concepção da realidade, determinados graus na capacidade de abarcá-la e na profundidade de penetração nela." 16

A redação abarca a realidade de um determinado modo (ficcional) em função das características do gênero discursivo em que se consolida. Se outro fosse o gênero,

\footnotetext{
15 Aliás, uma vestibulanda capaz de elencar - através da voz de seu narrador - esses textos narrativos possivelmente os conhece bem ou tem alguma familiaridade com eles. Esse conhecimento, supomos, reflete-se no seu modo de desenvolver a narrativa, inclusive em termos de estrutura composicional.

${ }^{16}$ Cada género es capaz de abarcar tan solo determinados aspectos de la realidad. Cada género posee determinados principios de selección, determinadas formas de visión y concepción de la realidad, determinados grados en la capacidad de abarcarla y en la profundidad de penetración en ella.
} 
possivelmente distinto seria o tratamento temático. Caso se transpusesse, por exemplo, os acontecimentos narrados a uma notícia de jornal, crônica ou poema, diverso seria o texto. Isso porque o conteúdo temático e gênero discursivo estão invariavelmente vinculados. O desenvolvimento do tema se dá segundo certas possibilidades do gênero discursivo em que se materializa.

\subsection{ESTILO}

Bakhtin propõe uma aliança entre estilo e gênero discursivo, postulando que o "estilo está indissoluvelmente ligado ao enunciado e às formas típicas de enunciados, ou seja, aos gêneros do discurso" (BAKHTIN, 2003 [1952-1953], p. 265).

Essa observação bakhtiniana parece ser corroborada pela redação, que apresenta propriedades estilísticas comuns a textos narrativos. O texto da vestibulanda traz, por exemplo, inúmeras figuras de linguagem, entre as quais citamos: a metáfora em "pátria mãe gentil", usada para simbolizar o Brasil; a personificação em "esse palpite segredoulhe ao ouvido"; e uma espécie de metáfora acrescida de hipérbole em "conspiração muito maior, gigante pela própria natureza". Opções estilísticas que são visivelmente dialógicas em dois dos três exemplos: tanto a expressão "pátria mãe gentil", quanto "gigante pela própria natureza" dialogam com o Hino Nacional do Brasil. As eleições estilísticas, portanto, não são apenas escolhas individuais do enunciador, pois se acomodam ao gênero discursivo e mantêm contatos dialógicos com outras vozes.

Entre as opções lexicais da candidata, destacamos as seguintes expressões que compõem o perfil nacionalista de Policarpo, conferindo ao mesmo tempo certo tom "arcaico" à narrativa: "Constituição regente", "arraigado e ingênuo patriotismo", "os óculos auriverdes", "o marasmo em que sua vida submergira desde sua recente aposentadoria", "Ao cabo de alguns minutos, decidiu-se; ato contínuo", "Finda a explanação", "um súbito palpite perpassou a mente", "funesto palpite", "subjugar todo um povo", "delatado pela extrema ignorância", "milhões como ela que por aí grassam", "começou a fenecer" (grifos nossos). Mesmo que a seleção desses termos seja bastante subjetiva - outro analista poderia selecionar termos diferentes para ilustrar as opções estilísticas da candidata -, arriscamo-nos a dizer que, de algum modo, as palavras grifadas atestam escolhas lexicais da autora em prol de um tom patriótico e antiquado ao seu texto. Tom que contribui para a composição do personagem e que condiz com o desenvolvimento do tema.

Ainda quanto às opções lexicais e fraseológicas da vestibulanda, apreciemos a fala da personagem que derramou o óleo na privada. Sua voz é bastante informal, especialmente quando confrontada ao restante do texto. Isso se explica, pois se trata da reprodução de uma fala, comumente mais informal que o registro escrito. Além disso, simula o discurso de uma "ignorante". Transcrevamos o fragmento: "O senhor está falando daquela 'lataiada' velha que meu pai guardava no galpão? Aquilo não prestava não... Meu velho era meio doido, trabalhava na refinaria e cada semana trazia uma porcaria daquelas p'ra cá. Meu irmão disse que aquilo era como um tal de paiol pronto p'ra explodir, que eu tinha que me livrar daquilo. Então, como eu sei que faz fogo, joguei tudo fora, um por um, na 'privada'!". 
A coloquialidade dessa fala se evidencia, por exemplo, em expressões como "lataiada" - aliás, destacada por aspas no texto, como para mostrar que não é do narrador (ou da candidata) -; na abreviação "p'ra"; na abstrusa construção de "um tal de paiol"; no emprego de "porcaria", vocábulo bastante distante do matiz erudito da narração.

A Comvest, é importante ressaltar, abona registros informais nos textos narrativos:

\begin{abstract}
Você [candidato] deverá demonstrar, em sua redação, capacidade de exprimir-se de forma adequada ao estilo escrito e formal. Em certas circunstâncias poderão ser aceitas modalidades próprias da linguagem oral (por exemplo, se você estiver reproduzindo um diálogo coloquial, em uma narrativa). Você deverá também revelar um bom domínio das regras gramaticais da língua culta, do sistema ortográfico e dos recursos de pontuação. (COMVEST, 1999, p. 34)
\end{abstract}

O vestibulando, portanto, pode esboçar "modalidades próprias da linguagem oral" na reprodução de "um diálogo coloquial". A informalidade da voz da personagem preenche justamente essa hipótese colocada pela Comvest. Vale notar ainda que a Comvest pontua ser essa abertura possível "em uma narrativa". Assim, a instituição parece reconhecer a narrativa como mais flexível aos registros, na medida em que possibilita a reprodução de várias vozes. De algum modo, isso reflete a flexibilidade do gênero, assim colocada por Bakhtin (2003 [1952-1953], p. 265):

\begin{abstract}
Todo enunciado - oral e escrito, primário e secundário e também em qualquer campo da comunicação discursiva - é individual e por isso pode refletir a individualidade do falante (ou de quem escreve), isto é, pode ter estilo individual. Entretanto, nem todos os gêneros são igualmente propícios a tal reflexo da individualidade do falante na linguagem do enunciado, ou seja, ao estilo individual. Os gêneros mais favoráveis [são os] da literatura de ficção $[\ldots]$.
\end{abstract}

Precisamente por ser uma narrativa ficcional, é cabível um estilo menos formal, a conferir mais verossimilhança à voz da "ignorante" representada no texto. De nosso ponto de vista, esse exemplo atesta como certas escolhas estilísticas se pautam pelo gênero discursivo.

Quanto às opções fraseológicas, assinalamos que, das vinte e três frases que compõem o texto, apenas quatro são períodos simples. Isso possivelmente ocorre porque através dos períodos compostos o narrador pode articular melhor os eventos narrativos bem como tecer considerações a respeito de como esses fatos afetam o protagonista Policarpo.

Do exposto acima, avaliamos que o estilo pode comportar opções individuais do autor, embora as escolhas estilísticas se ajustem ao gênero discursivo e possam se valer de elos dialógicos. Como vimos, certas marcas estilísticas do texto se revelam dialógicas, quando retomam, por exemplo, o Hino Nacional do Brasil. 
Procuramos, através de nosso exame, indicar ligações entre os elementos constitutivos do enunciado. Vimos, por exemplo, que o título da narração, sua epígrafe e o corpo propriamente dito da narração ocupam espaços composicionais específicos, que se inter-relacionam e comportam o desenvolvimento do tema. Assim, a estrutura composicional efetivou-se apenas ao veicular o tema, do mesmo modo que a execução do conteúdo temático se deu de acordo com os limites e as possibilidades da forma.

Observamos também eleições estilísticas da candidata que, ao traçarem um personagem nacionalista, contribuem igualmente para a construção do tom "antiquado" da narrativa. Como apontamos, acreditamos que essas opções estilísticas estão em consonância com o desenvolvimento temático do texto, matizando adequadamente as peripécias do nacionalista Policarpo.

Além das relações entre o tema, a estrutura composicional e o estilo, discorremos ainda a respeito do caráter dialógico do enunciado. Avaliamos, assim, que o desenvolvimento do conteúdo temático da redação se liga à proposta e à coletânea do vestibular, pois é respondendo às indicações da prova que a candidata se põe a narrar as aventuras do patriótico Policarpo em seu afã por elucidar o suposto crime ambiental.

Do mesmo modo, compreendemos a estrutura composicional a partir de relações dialógicas, embora reconheçamos serem menos evidentes os vínculos dialógicos nesse caso. Conforme expusemos, supomos ser a partir de sua educação escolar - e talvez extraescolar - que a vestibulanda traz as bases atuantes na forma composicional de seu texto. Sugerimos ainda que a estudante pode ter se amparado em indicações presentes em materiais publicados pela Comvest.

O estilo da redação, igualmente, evidencia arranjos dialógicos, na medida em que certas escolhas lexicais da vestibulanda acolhem vozes de outros textos, exteriores à sua redação.

Ao observar os elementos constitutivos do gênero em suas inter-relações e ao examiná-los a partir de seus vínculos dialógicos, esperamos que esse exemplo explicite como o enunciado resulta da conjugação de conteúdo temático, construção composicional e estilo e como esses elementos estão alicerçados em elos dialógicos.

Através da avaliação desse enunciado, pretendemos, em algum sentido, atender à crítica de Brait e Pistori (2012, p. 373), quando observam que "o conceito de gênero não se reduz a uma caracterização do discurso por meio dos três termos conhecidos e reconhecidos a partir da leitura do texto de Bakhtin 'Os gêneros do discurso' - tema, composição e estilo [...]”. Além de reconhecer esses três elementos, é preciso observálos em suas interações, ver como tema, composição e estilo se influenciam e se constituem conjuntamente. Além disso, é imprescindível entender que os três elementos constitutivos do enunciado estão necessariamente embasados por relações dialógicas. Conforme afirmamos em trabalho anterior: "o tema é o tema no dialogismo, a construção composicional é a construção composicional no dialogismo e o estilo é o estilo no dialogismo" (MACIEL, 2011, p. 36).

Lembramos, por fim, que, apesar das inúmeras - e por vezes contundentes críticas às adaptações que se faz das discussões bakhtinianas, parece válido procurar empregar os ensinamentos bakhtinianos a outros contextos textuais e discursivos, para 
além daqueles já estudados pelos intelectuais do Círculo. Como bem observa Schnaiderman (2005 [1997], p. 20): “A meu ver, por mais relevância que tenham os trabalhos de teoria literária baseados em Bakhtin, e por mais que eles ainda nos possam dar, o que ele deixou delineado para a exploração de outros campos parece particularmente rico em sugestões".

Nosso exemplo de análise, uma redação de vestibular, vincula-se à esfera do ensino, pois, mesmo que redigido fora da escola, o "gênero redação de vestibular" "reflete e refrata, sobretudo, as práticas de escrita e de leitura que circulam na escola" (cf. BRITO, 2011, p. 188). O texto da vestibulanda, portanto, está algo distante dos textos da esfera literária que são os objetos principais (embora não únicos) dos exames empreendidos pelo Círculo. Ainda assim, realizar uma análise "bakhtiniana" de uma redação parece-nos relevante, desde que não se perca de vista a complexidade das colocações bakhtinianas. Colocações essas que, se tiveram por escopo principal exemplos literários - com destaque para a prosa dostoievskiana -, não ignoram as questões de ensino, como vem expor a recente publicação em português de "Questões de estilística no ensino da língua ${ }^{17}$ " (BAKHTIN, 2013 [1944-1945]), que apresenta uma "nova" faceta de Bakhtin, a faceta de professor.

\section{REFERÊNCIAS}

BAKHTIN, M. M. (1924). O problema do conteúdo, do material e da forma na criação literária. In: Questões de literatura e de estética: a teoria do romance. Trad. Aurora Fornoni Bernardini et al. 3. ed. São Paulo: Unesp; Hucitec, 1993.

([1944-1945]). Questões de estilística no ensino da língua. Trad. Sheila Vieira Grillo e Ekaterina Vólkova Américo. São Paulo: Ed. 34, 2013. ([1952-1953]). Os gêneros do discurso. In: . Estética da criação verbal. Trad. Paulo

Bezerra. 4. ed. São Paulo: Martins Fontes, 2003.

BEZERRA, P. (2010). Prefácio: Uma obra à prova do tempo. In: BAKHTIN, M. M. (1929/1963).

Problemas da poética de Dostoiévski. Tradução Paulo Bezerra. 5. ed. (2. tiragem). Rio de Janeiro: Forense Universitária, 2011. p. v-xxii.

BRAIT, B.; PISTORI, H. L. C. A produtividade do conceito de gênero em Bakhtin e seu círculo. Alfa: Revista de Linguística (Online), v. 2, n. 56, p. 371-401, 2012.

BRITO, L. A. N. Discurso, leitura e produção textual: uma análise discursiva da escrita de préuniversitários. 2011. 199 f. Tese (Doutorado em Filologia e Língua Portuguesa) - Faculdade de Filosofia, Letras e Ciências Humanas, Universidade de São Paulo, São Paulo, 2011.

COMVEST. (1999). Manual do Candidato 99. Coordenadoria Executiva dos Vestibulares da Unicamp. [Campinas]: [s.n.]. (2000). Redações do Vestibular Unicamp 2000. Pró-Reitoria de Graduação, Comissão Permanente para os vestibulares, Pró-Reitoria de Extensão e Assuntos Comunitários. Campinas: Editora da Unicamp.

CORRÊA, M. L. G. Encontros entre prática de pesquisa e ensino: oralidade e letramento no ensino da escrita. Perspectiva, Florianópolis, v. 28, n. 2, p. 625-648, jul./dez. 2010.

GINZBURG, C. (1986). Sinais: raízes de um paradigma indiciário. In: Mitos Emblemas Sinais: Morfologia e História. Trad. Federico Carotti. São Paulo: Companhia das Letras, 1991. p.143-179.

GOMES-SANTOS, S. N. O gesto de recontar histórias: gêneros discursivos e produção escolar da escrita. 1999. 216f. Dissertação (Mestrado em Linguística Aplicada) - Instituto de Estudos da Linguagem, Universidade Estadual de Campinas, Campinas, 1999.

\footnotetext{
${ }^{17}$ Abreviação para o título em russo Questões de estilística nas aulas de língua russa no ensino médio.
} 
GRILLO, S. V. C. Épistémologie et genres du discours dans le cercle de Bakhtine. Linx, Nanterre, v. 56, p. 19-38, 2007.

KRISTEVA, J. (1967). A palavra, o diálogo e o romance. In: (1969). Introdução à semánalise. Trad. Lúcia Helena França Ferraz. 3. ed. revista e aumentada. São Paulo: Perspectiva, 2012.

MACIEL, L. V. C. Gênero e estilo nas melhores redações do vestibular Unicamp. 2008. 185 p. Dissertação (Mestrado em Linguística Aplicada) - Instituto de Estudos da Linguagem, Universidade Estadual de Campinas, Campinas, 2008.

Além de "Os gêneros do discurso". Caderno de Estudos Linguísticos, v. 1, n. 53, p. 27-38, 2011. Relações dialógicas em narrativas. 2014. 360p. Tese (Doutorado em Linguística Aplicada) Instituto de Estudos da Linguagem, Universidade Estadual de Campinas, Campinas, 2014.

MARCUSCHI, L. A. (2002). Gêneros textuais: definição e funcionalidade. In: BEZERRA, M. A.; DIONÍSIO, A. P.; MACHADO, A. R. (Orgs.) Gêneros textuais e ensino. 4. ed. Rio de Janeiro: Lucerna, 2005, p. 20-39.

MEDVEDEV, P. N./BAKHTIN, M. M. (1928). El método formal en los estudios literarios: Introducción crítica a una poética sociológica. Trad. Tatiana Bubnova. Madrid: Alianza Editorial, 1994.

SCHNAIDERMAN, B. (1997). Bakhtin 40 graus (Uma experiência brasileira). In: BRAIT, B. (Org.) Bakhtin, dialogismo e construção do sentido. 2. ed. ver. Campinas/SP: Editora da Unicamp, 2005.

VAUTHIER, B. Préface. In: VAUTHIER, B. (Org.). Slavica Occitania Numéro 25 - Mikhaïl Bakhtine, Valentin Volochinov et Pavel Medvedev dans les contextes européen et russe. Toulouse, p. 9-43, 2007. VOLOŠINOV, V. N. (1929). Marxism and the Philosophy of Language. Trad. Ladislav Matejka e I. R. Titunik. Cambrigde: Harvard University Press, 1986.

\title{
Recebido em: 18/02/15. Aprovado em: 18/07/15.
}

Title: Constitutive elements of utterance in its dialogic relationships: an example of analysis

\begin{abstract}
Author: Lucas Vinício de Carvalho Maciel
Abstract: From proposals of the Bakhtin Circle, we discuss how the dialogical links can appear in a real utterance. For this purpose, we analyzed a narrative composition written during the first phase of Unicamp (State University of Campinas) entrance exam in 2000. This text is an adequate example to investigate the dialogical links because at this context, the candidate needs to dialogue with the instructions of the test and with a collection of texts that underlies the writing proposal of the essay. The analysis proposed shows how the dialogic relationships, which are constitutive of discourse genre, are manifested in the thematic content, in the compositional construction and in the style of the utterance.
\end{abstract}

Keywords: Dialogic relationships. Narration. Unicamp entrance exam.

Título: Los elementos constitutivos del enunciado en sus relaciones dialógicas: un ejemplo de análisis

\section{Autor: Lucas Vinício de Carvalho Maciel}

Resumen: Desde propuestas del Círculo de Bajtín, discutimos cómo los enlaces dialógicos pueden se presentar en un enunciado real. Para este fin analizamos una prueba de escritura narrativa compuesta durante la realización de la primera fase de la prueba de acceso a Unicamp 2000. El texto es un buen ejemplo para investigar los enlaces dialógicos, pues el pretendiente precisa dialogar con las instrucciones de la prueba y con una colección de textos que basa la propuesta de escritura. El análisis propuesta muestra cómo las relaciones dialógicas constitutivas del género discursivo se manifiestan en el contenido temático, en la construcción de la composición y en el estilo de ese enunciado.

Palabras-clave: Relaciones dialógicas. Narración. Prueba de acceso Unicamp. 